\title{
Supply, Demand and Policy Issues for Use of Aspen'1
}

\author{
by
}

\author{
James Beck, Luis Constantino, William Phillips, and Mark Messmer ${ }^{2}$
}

\begin{abstract}
There is currently considerable expansion of aspen utilization in the Prairie Provinces, and particularly in Alberta. This expansion includes the establishment of both oriented strand board mill capacity and pulp mill capacity. The pulp mill expansion is geared predominantly to aspen utilization. These developments arise out of the adoption of new technology and are demand driven. In this paper, the derived demand for aspen roundwood is examined. It includes a review of panel product and pulp consumption patterns. On the supply side, factors such as stumpage availability are examined. There is some uncertainty about the economic viability of aspen utilization as a result of demand and trade patterns as well as domestic and trade policies. The paper concludes with an examination of some current policy issues and the manner in which they may affect the future of aspen utilization.
\end{abstract}

\section{Résumé}

Les provinces des Prairies, notamment l'Alberta, utilisent maintenant de plus en plus le bois du peuplier faux-tremble, ce qui s'est traduit par une augmentation de la capacité des usines de panneaux de grandes particules orientées et des usines de pâte. L'expansion des usines de pâte est surtout fonction de l'utilisation du bois de peuplier faux-tremble. L'adoption d'une nouvelle technologie et la force de la demande en sont les principales raisons. Le présent document traite de la demande dérivée pour le bois rond de peuplier fauxtremble. II présente notamment un examen des rythmes de consommation des pâtes et des panneaux. Sur le plan de l'approvisionnement, des facteurs comme la disponibilité du bois sur pied sont également abordés. La rentabilité économique de l'utilisation du bois de peuplier faux-tremble laisse planer une certaine incertitude en raison de la structure de la demande et des échanges commerciaux ainsi que des politiques nationales et commerciales. Les auteurs terminent en abordant certaines questions politiques d'actualité et l'impact qu'elles pourraient avoir sur le futur de l'utilisation du bois de peuplier faux-tremble.

\section{Introduction}

Market conditions, resource availability and technology are major factors influencing public policy decisions. Recent development and adoption of wood processing technology coupled with increasing wood products demand has resulted in considerable reassessment of wood supply. This has been particularly true in western Canada which is now in a wood using expansion phase centred primarily on aspen utilization. Forest management policies in the western provinces have traditionally centred on the harvesting, regeneration, and treatment of conifer. However, the advent of substantially increased aspen stumpage values has important implications for these existing policies.

\footnotetext{
Paper presented at the Joint Technical Session, "Managing for Aspen - A Shared Responsibility." of the Forest Ecology. Silviculture and Tree Improvement, Forest Management, and Forest Economics and Policy Working Groups at the CIF Annual Meeting. Prince Albert. Saskatchewan, September 1988

2James Beck is Professor and Chairman, Department of Forest Science: Luis Constantino is Assistant Professor. William Phillips is Professor and Chairman, and Mark Messmer is Research Assistant, Department of Rural Economy. Both departments are in the Faculty of Agriculture and Forestry, University of Alberta, Edmonton, Alberta T6G $2 \mathrm{H} 1$
}

A recent buzzword in forest management in Alberta and other provinces is aspen utilization. Suddenly a species that until recently was treated as a weed by forest managers has gained commercial value. New oriented strand board (OSB) mills that utilize aspen have been established and have performed successfully in their first years of operation. New pulp mills that can process aspen chips are planned, and, if they are built, the pulp processing capacity in the province will more than double. This phenomenon caught the provincial forest sector by surprise and casts doubt on the wisdom of traditional forest management policies geared primarily to softwood management. Suddenly the practice of trying to sustain forest production on the basis of traditional coniferous species spruce and pine - seems questionable. Besides existing Crown lands, the private aspen forests close to the new processing centres have gained economic relevance and revealed the lack of support to private forestry in the province.

The purpose of this paper is to review wood supply and demand prospects and to analyze forest management policy in light of recent and prospective supply and demand changes. The wood supply discussion focusses on aspen availability and 


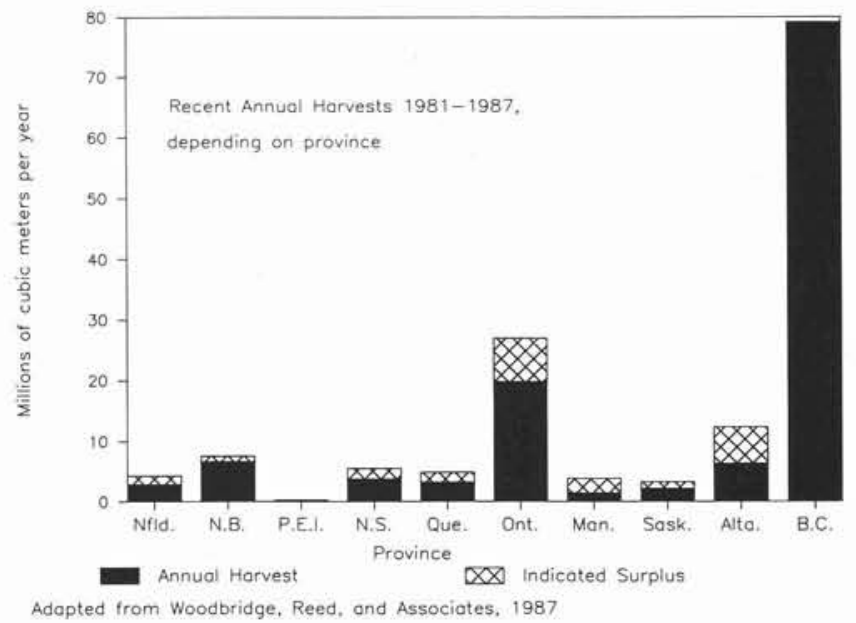

Figure 1. Economically accessible $A A C$ and annual harvest of softwoods by province.

utilization in western Canada. The demand analysis is primarily centred on fibre and, in particular, pulp. Policy implications draw on Alberta experience to illustrate the analytical content.

\section{Supply and Demand}

A comparison of economically accessible annual allowable cut $(A A C)$ figures with harvest rates across the country indicate that the percentage of surplus hardwood tends to be somewhat higher than that for softwood (Figures 1 and 2). In western Canada, only Saskatchewan has less than a $90 \%$ hardwood surplus (68\%). Virtually all of the surplus AAC in the four western provinces is aspen (Figure 3 ). It amounts to some 12 million $\mathrm{m}^{3}$ of AAC of which over half is in Alberta (Figure 2). An examination of pulpwood utilization across Canada between 1975 and 1984 shows that 8 to 10 times more softwood than hardwood has been used. However, hardwood use has doubled in volume with little relative change in softwood (Figures 4 and 5).

In Alberta, aspen utilization is increasing rapidly. Three OSB mills utilize approximately $800000 \mathrm{~m}^{3}$ of aspen annually.

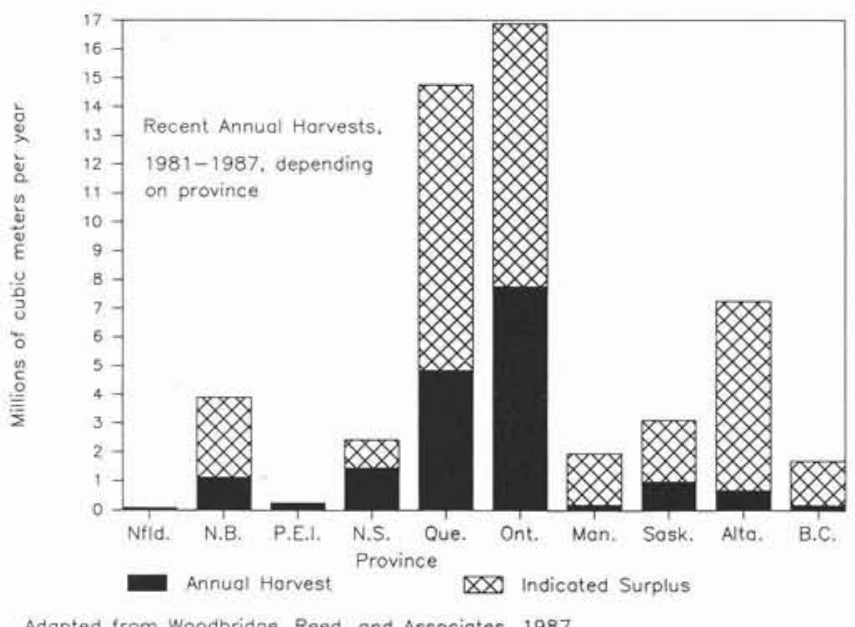

Figure 2. Economically accessible $A A C$ and annual harvest of hardwoods by province.

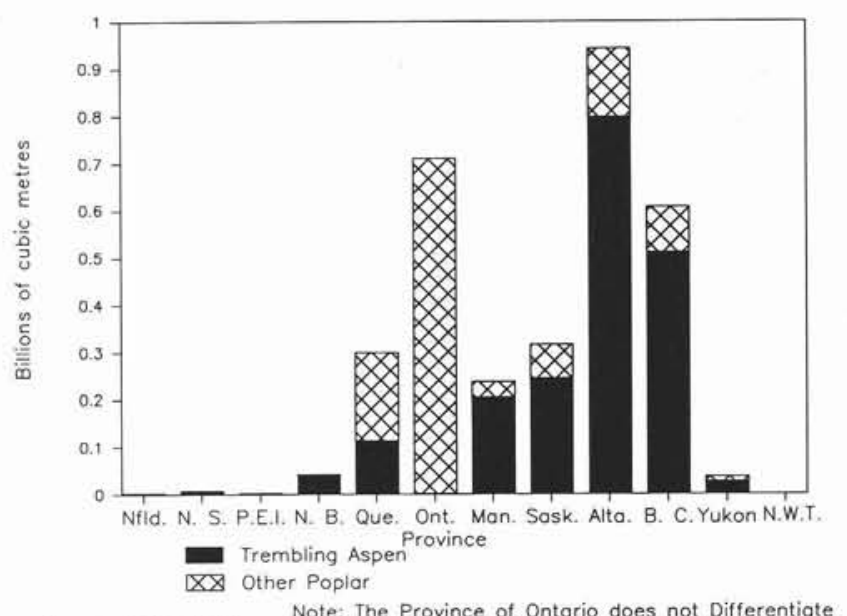

Source: CFS, 1986. Note; The Province of Ontario does not Differentiate

Figure 3. Inventory of trembling aspen and other poplars as components of gross hardwood pulp volume.

New pulp and paper mills at Peace River and Whitecourt will utilize about 1.5 million $\mathrm{m}^{3}$ of aspen per year or more, which will triple the volume used in 1987 (Bamsey 1987 and Rabik 1988). In addition, existing pulp mills are producing or plan to produce aspen pulp as well as conifer pulp. These commitments represent a significant portion of available aspen AAC but considerable unutilized volumes still exist (Figure 6).

Should this expansion continue, and increased demand prospects for pulp discussed below suggest it will, forest management policy must shift away from a focus primarily on softwood to one that incorporates aspen. The rate and extent of expansion will depend on the economic climate, and in particular, global wood fibre demand.

Despite price fluctuations in wood products and output expansion around the world, prospects for the industry appear bright. Demand analysis under various supply projections show varied results. Wood products consumption figures range from rather conservative increases projected by World Bank to very optimistic increases projected by FAO. (Figures 7, 8 and 9). Despite differences among them, all major

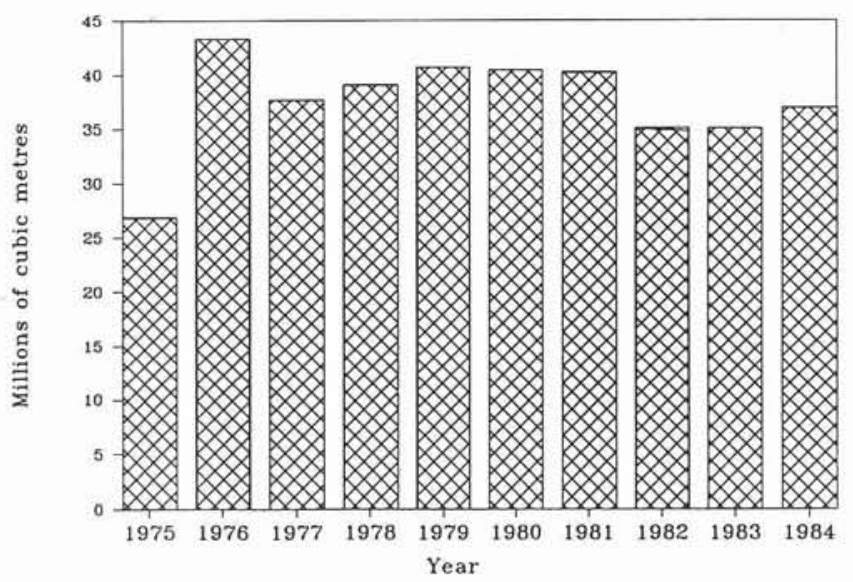

Source: Stats. Can. 36-204

Figure 4. Roundwood softwood pulpwood used in Canada, 19751984. 


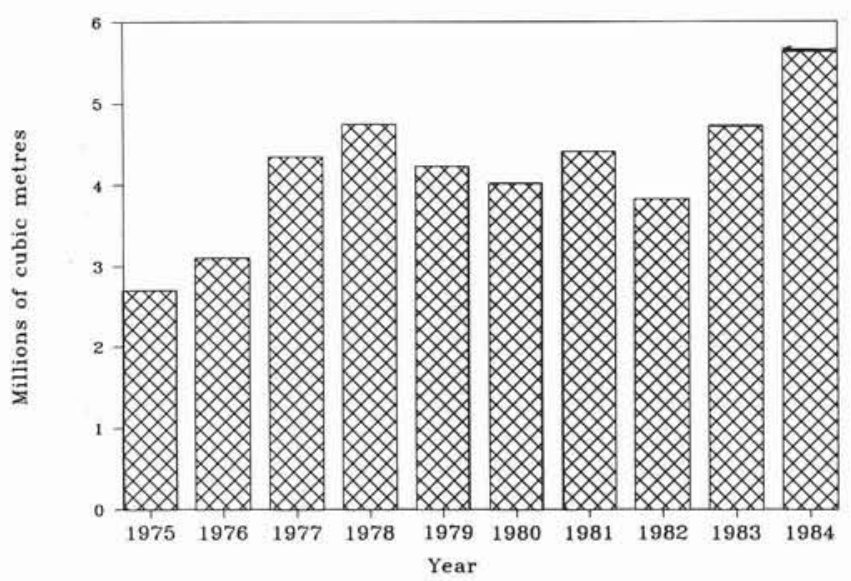

Source: Stats. Can. 36-204

Figure 5. Roundwood hardwood pulpwood used in Canada, 1975 1984.

forecast sources predict expansion. World lumber consumption increases are expected to be more modest than those for wood panel products and paper and paperboard products. Our own preliminary results at the University of Alberta serve to confirm these projections. In particular, consumption of waferboard/OSB panels shows continued expansion relative to other panels (Figures 10 and 11).

Increases in world demand will put upward pressure on prices and stimulate continued expansion. This expansion will lead to increased harvest of existing inventories. A second source of supply will be from new lands brought into production due to expansions in the extensive margins of land use. Likely locations include the large tropical forests in the Amazon and temperate forests in Siberia and Canada. In much of western Canada the new demand for aspen will probably be met from private forest land which heretofore was not considered an important supply source. A third source is likely to be from increased utilization of smaller sizes and lower value species such as aspen in existing forests. A fourth source of supply will be increased productivity due to investments in intensive forest management, notably plantations in Latin America and the southern United States.

Unallocated Accessible (28.1\%)

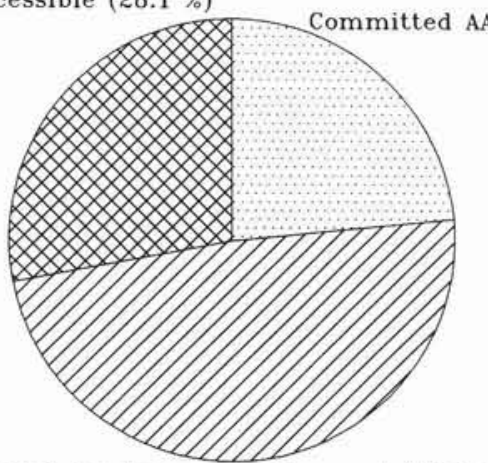

Designated for Future Development (48.5\%)

Source: Dermott, 1988

Figure 6. Alberta deciduous annual allowable cut allocation, 1988.

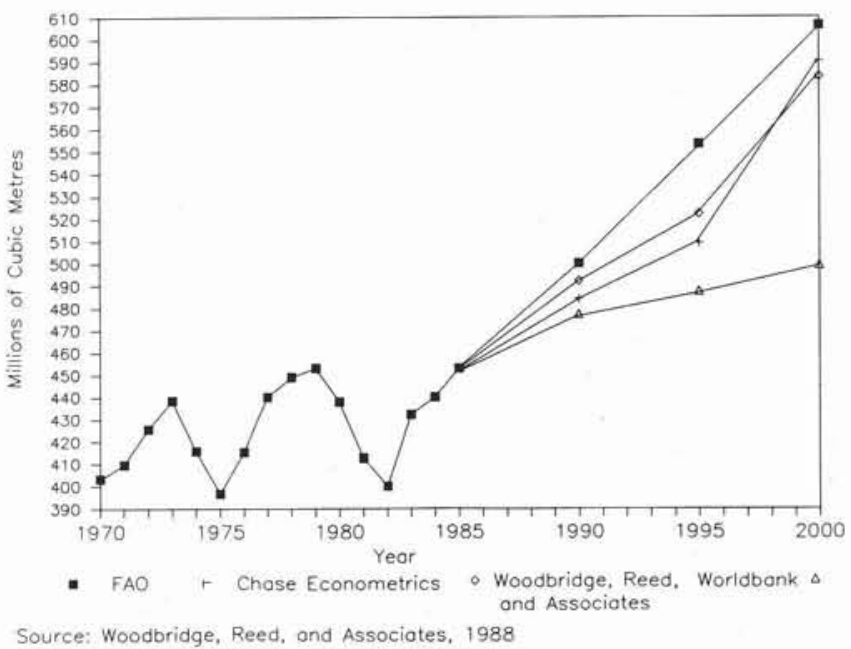

Figure 7. Historical and projected world lumber consumption.

Given global integration of forest product markets, the lack of detailed information on characteristics of inventory, costs of recovery and profitability of investments in various parts of the world, it is impossible to predict the relative importance of each source of potential supply increase (increased harvest of existing inventories, increased extensive margins, increased utilization and increased productivity). It is interesting to speculate on what will happen in Canada (particularly western Canada) with each of these four ways of increasing supply. If greater supply is brought about by increased harvest of existing inventories, aspen wil probably make up a large portion of this increase in supply since much of the existing inventory is aspen. If utilization is increased, much of what could be added from existing areas harvested is aspen. If utilization is increased, much of what could be added from existing areas harvested is aspen. If increases in supply are sought by intensive management, aspen may or may not play an important role in the increased supply. Intensive management activities could promote production of either conifer or aspen volume, but there is no intuitive evidence to suggest aspen would be favored However, the recent expansion of aspen utilization in Canada, continued excess supply in accessible sites, and projected

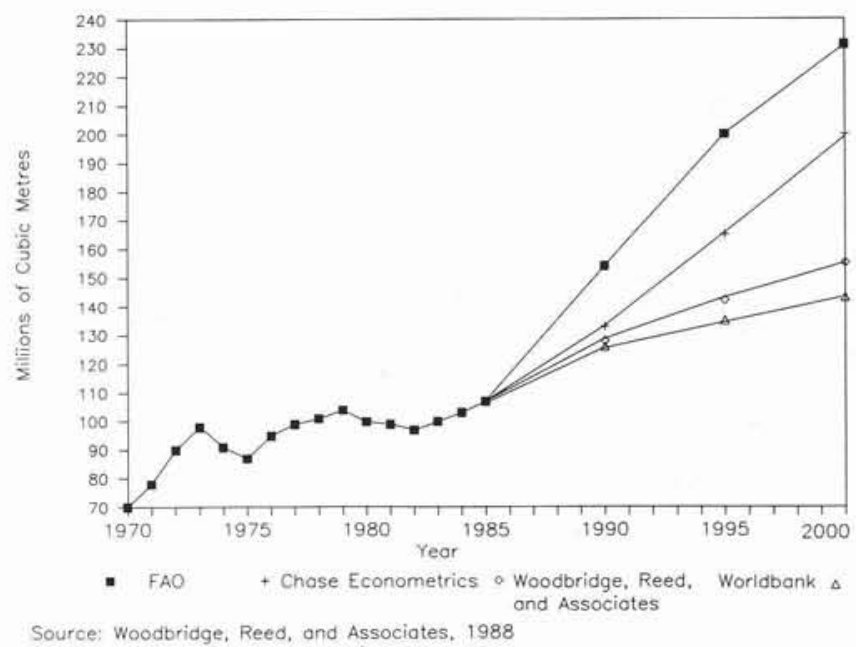

Figure 8. Historical and projected world wood based panel consumption. 


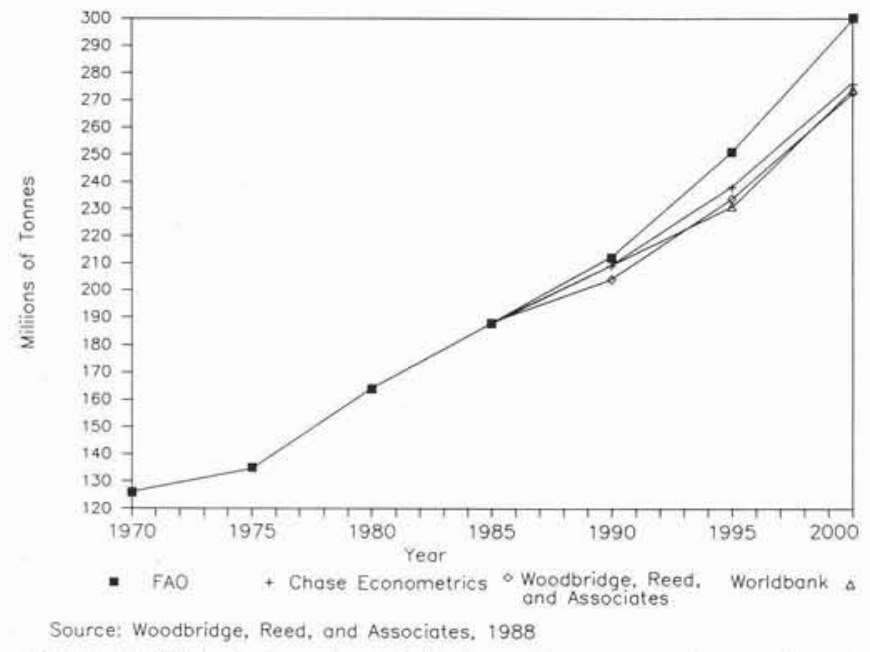

Figure 9. Historical and projected world paper and paperboard consumption.

increased in demand for panels and pulp and paper, all suggest that increased utilization of apsen will be an important and significant development, particularly in western Canada and notably Alberta. This development has a number of implications for forest management policy.

\section{Policy}

The policy issues regarding use of aspen need to be examined by looking at particular policy issues related to: (a) harvest and use of existing forests and (b) establishment of future forests. Both groups of policies are highly affected by a conifer bias which evolved historically from times and conditions in which aspen was considered to be a valueless weed. Now that it is no longer valueless we must modify our policies to appropriately recognize this new wealth.

In some areas of western Canada, because of past efficient fire protection, large areas of overmature aspen have developed. Utilization policies such as "cut oldest first" may lead an operation, at certain levels of utilization, to continually utilize only "rotten apples from the barrel". This policy may inhibit initial development or lead to closure of an existing

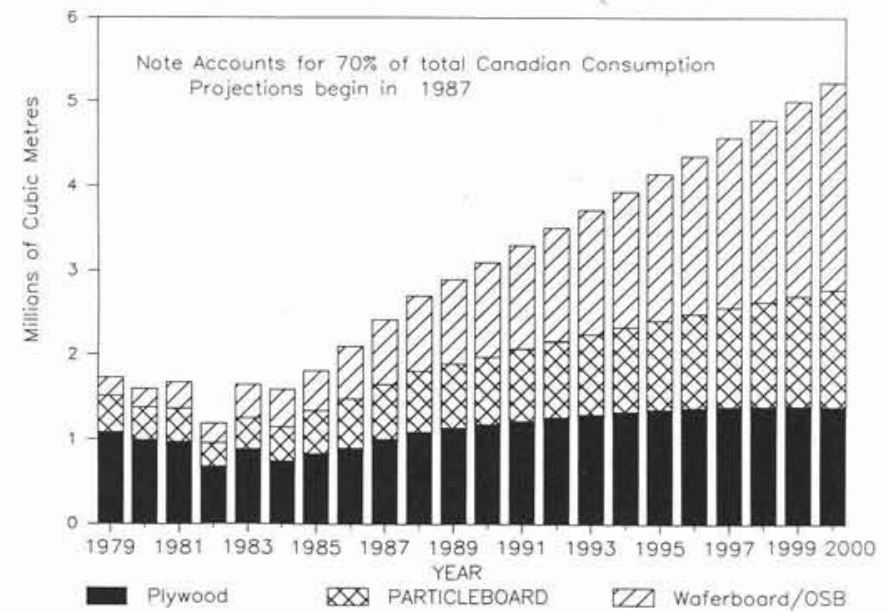

Source: Gellner, 1988

Figure 10. Historical and projected Canadian panel board consumption. firm's mill facilities. At least less profitability for any company working with overmature aspen could result and, in turn, lead to lower returns to society. In recognition of this problem, some Lake States of the United States actually plow down aspen stands over a certain age, thus starting the renewal process to get young vigorous stands of greater merchantability. "Oldest first" is not always bad, however. A careful examination of each allowable cut unit should be undertaken to see whether it is appropriate or not to develop an alternative.

At the recent symposium in Edmonton on mixedwood, several speakers spoke of the problems created when two operators held overlapping cutting rights in the same area one for conifers and one for poplar (Samail. 1988). If either operates as if holding sole rights to the area, unacceptable waste of the other species group seems to occur. Suggested solutions included creation of an independent harvesting unit that harvests both groups of species and then supplies the mills involved. Certainly this is not the only possible solution. Appropriate regulations and policies, harvesting technologies, and ethics about the future forest can be developed to allow partial harvesting of either conifer or poplar in a way that causes minimal acceptable damage to the remaining species groups.

Many would argue that each land unit should be analyzed and placed in either a conifer or hardwood land base - a land base fix. Once designated, priority would be given to the designated type and the other harvested only in ways that are not detrimental to the species of prime designation. While there are large areas of essentially pure conifer or pure hardwood where this policy works, there is also a vast area of mixedwood in the boreal forest where significant volumes of both conifers and hardwood are growing together. In these areas, multiple operators often create a major problem. Conifer bias could lead one to question whether harvesting of the 70-90 year-old mature aspen should be allowed when significant damage may or will occur to the $50-70$ year-old immature spruce. Yet this conifer bias dictates growth for another $30-50$ years until the spruce is mature, ignoring the fact that the aspen will probably be so overmature that it is practically valueless. Thus those who advocate this land base fix for a mixedwood unit still have a problem - where does one draw the line? What land base does a stand with $50 \mathrm{~m}^{3} / \mathrm{ha}$ of conifer on a rotation of 120 years, and $210 \mathrm{~m}^{3} / \mathrm{ha}$ of aspen

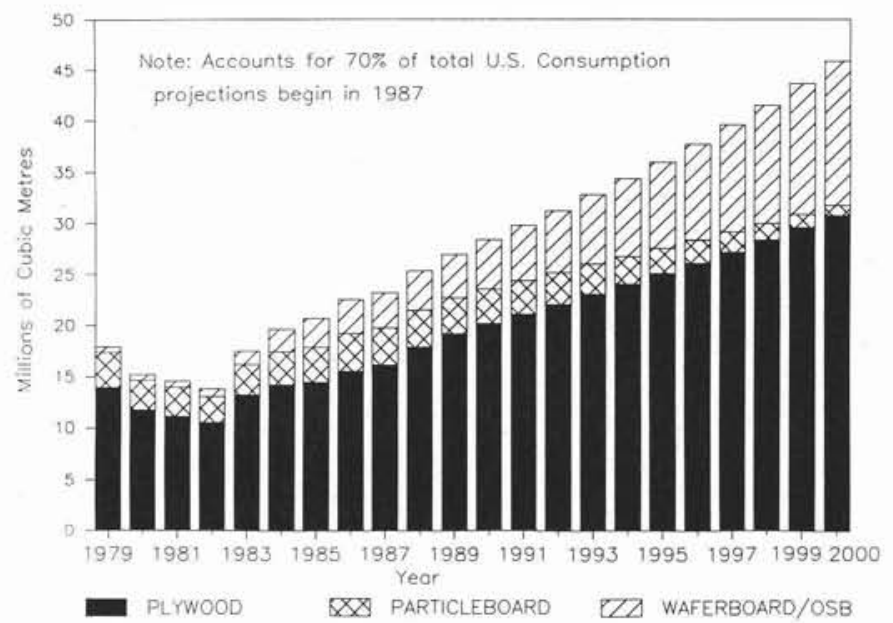

cer. Fellner. 1988

Figure 11. Historical and projected U.S. panel board consumption. 
on a rotation of 80 years belong to? If one thinks the answer to that is simple, try combinations with more equal mean annual increments or volumes per hectare. Just maybe one should manage for both, not giving prominence to either conifer or hardwood. Is it so hard to think that we need policies that lead toward maximization of total net returns to society from the combined total of conifer and hardwood? Aside from technological constraints in harvesting on mixedwood types, economic theory would suggest that there may be considerable inherent value in flexibility of management policy in mixedwood stands given the stochastic nature of stand growth and changes in economic and technological climates.

Policies relating to renewal of the forest are just as knotty. Policy should be clear on reforestation goals. Whether the goal is a conifer, a hardwood or a mixedwood stand, supporting policies and regulations that are biologically and economically feasible are necessary. Before discussing this issue further, we might observe that the regenerated mixedwood forests of the northeastern United States and eastern Canada have a higher proportion of poplar in them than the virgin forest first harvested. Many Albertan's have smugly felt "this will not happen to us because we have strict conifer reforestation requirements" (note the conifer bias). Recent juvenile stand surveys by the Alberta Forest Service and industry indicate that in spite of the conifer-biased reforestation policy, the regenerated forests have a much larger hardwood component than the forest initially harvested. This fact is leading to conifer-biased pressures to remove the competition for conifers. Such issues as herbicide use and free-to-grow standards are entering the arena as possible solutions. If conifers are to be given priority, these practices may seem reasonable biologically and even economically if you assume poplar is worthless. However, earlier analysis in this paper suggests that poplar will certainly be worth something in $50-80$ years when the trees, to be eliminated now, will be harvested. Currently, headlines are being made about new processing facilities to use existing poplar which create new jobs, new investment and economic activity. This demonstrates that poplar is worth something now. On the other hand there is a push to be allowed to spend funds to eliminate it with herbicides. No wonder foresters and forest managers have little credibility with the politicians and general public on this issue. If rational management policies and prescriptions are to be developed, one must recognize that on mixed wood areas both conifers and hardwood must be

\section{Back Issues of Forestry Chronicle Required}

The Institute Head Office requires the following issues of The Forestry Chronicle. We will pay postage for any copies forwarded; contact $\mathrm{HO}$ first

Vol. 40, 1964, March

Vol. 50, 1974, October

Vol. 51, 1975, August

Vol. 53, 1977, All Issues

Vol. 54, 1978, June, August, October

Vol. 55, 1979, February, June, August

Vol. 56, 1980, June, August, October, December

Vol. 59, 1983, October

Vol. 61, 1985, April, June, August, October, December

Vol. 62, 1986, February, June

Vol. 64,1988 , August

J.H. Cayford, R.P.F. Executive Director regenerated. A possible solution may entail the single harvester of the existing stands mentioned earlier being responsible for regeneration of both species in a manner to maintain or enhance total allowable cut with certain limits set regarding the proportion of conifer and hardwood in that $A A C$.

There seems little doubt that a whole new or modified set of policies on use of the existing stands and the regeneration of future forests must and will evolve. These policies must recognize that aspen and other hardwoods are not worthless and that joint production of conifers and hardwood in certain proportions will be the goal. Economically, biologically, environmentally and politically the boreal mixedwood can never be turned into just boreal conifer and just boreal hardwood. Much of it must remain as mixedwood. The challenge is to develop policies that guide this evolution and avoid undue economic hardship.

\section{Acknowledgements}

The assistance of the Alberta Forest Service in providing inventory statistics is gratefully acknowledged. The authors also wish to thank Brett Gellner for his assistance.

\section{References}

Bamsey, C.R. 1987. Directory of Primary Wood Using Industries in Alberta, 1986. Alberta Forest Service and Canadian Forestry Service, Edmonton, Alberta. 265 pp.

Canadian Forestry Service. 1986. Selected Forestry Statistics, Canada. Can. For. Serv. Econ. Br. Inf. Rep. E-X-38. Economics Branch, Canadian Forestry Service Headquarters, Ottawa, Ontario.

Dermott, C.A. 1988. Personal communication 19 July 1988. Timber Manage. Br., Alberta For. Serv., Edmonton, Alberta

Gellner, Brett. 1988. Personal communication 15 August 1988. Dept Rural Economy, Univ. Alberta, Edmonton, Alberta.

Rabik, Brent. 1988. Personal communication 18 August 1988. Forest Industry Dev. Div., Edmonton, Alberta.

Samail, J.K., Ed. 1988. Management and Utilization of Northern Mixedwoods, Information Report NOR-X-296, Northern Forestry Centre, Canadian Forestry Service, Edmonton, Alberta. $163 \mathrm{pp}$

Statistics Canada. 1975-1984. Pulp and Paper Industries. Cat. No. 36-204 Annual

Woodbridge, Reed, and Associates. 1987. Canadian fibre supply. Unpub. Draft Rep.

Woodbridge, Reed, and Associates. 1988. Canada's forest industry, The next twenty years: prospects and priorities. Unpub. Draft Rep.

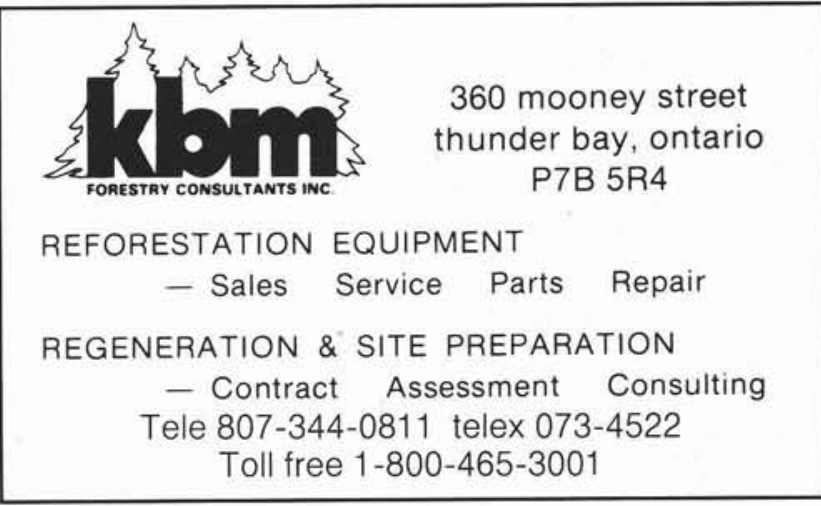

